\title{
Familial Amyloid Polyneuropathy treatment with Tafamidis - evaluation of one- and two-year treatment in Porto, Portugal
}

\author{
Teresa Coelho*, Ana Martins da Silva, Cristina Alves, Márcio Cardoso, Cecília Monteiro, Isabel Fonseca, \\ Carla Rodrigues, Vanessa Costa
}

From First European Congress on Hereditary ATTR amyloidosis

Paris, France. 2-3 November 2015

\section{Introduction}

Transthyretin (TTR) related Familial Amyloid Polyneuropathy presents as a severe sensory, motor and autonomic neuropathy. Tafamidis, an oral drug that stabilizes TTR preventing amyloid deposition, was recently introduced in Europe to delay neuropathy progression in ambulatory patients.

\section{Objectives}

To present Tafamidis efficacy and safety data after 12 and $24 \mathrm{M}$ treatment in patients from Porto, Portugal.

\section{Methods}

Patients were evaluated at baseline, 6, 12 and 24M. Adverse events and body mass index were registered. Renal, thyroid, and liver functions were screened. Neuropathy impairment score (NIS), the Norfolk Quality of life (QoL) - diabetic neuropathy total score (Norfolk), this last only at baseline, 12 and 24M. Patients were classified as responders (NIS change across 12 and $24 \mathrm{M}<2$ ) or nonresponders (if greater).

Paired samples $t$ test and ANOVA with repeated measures were used.

\section{Results}

163 patients (92 males), with a mean age of $41.04 \pm 11.68$ years [26-80] and a mean duration of disease of $29.66 \pm$ 17.48 months [4-90], completed a 12M evaluation. Body mass index remained stable throughout these $12 \mathrm{M}$ (3.13 vs. $3.14, \mathrm{p}<0.008)$.

\footnotetext{
Centro Hospitalar do Porto, Corino de Andrade Unit, 4099-001, Porto,
} Portugal

\section{Conclusion}

Tafamidis stabilized $69 \%$ of patients treated for one year and $57 \%$ of patients treated for two years. Even patients classified as non-responders according to NIS score showed a good response both on QoL and BMI. No major safety issues were detected. 
doi:10.1186/1750-1172-10-S1-025

Cite this article as: Coelho et al:: Familial Amyloid Polyneuropathy

treatment with Tafamidis - evaluation of one- and two-year treatment

in Porto, Portugal. Orphanet Journal of Rare Diseases 2015 10(Suppl 1):025.

Submit your next manuscript to BioMed Central and take full advantage of:

- Convenient online submission

- Thorough peer review

- No space constraints or color figure charges

- Immediate publication on acceptance

- Inclusion in PubMed, CAS, Scopus and Google Scholar

- Research which is freely available for redistribution

Submit your manuscript at 